\title{
The search for the ideal biocatalyst
}

\author{
Stephanie G Burton, Don A Cowan, and John M Woodley
}

\begin{abstract}
While the use of enzymes as biocatalysts to assist in the industrial manufacture of fine chemicals and pharmaceuticals has enormous potential, application is frequently limited by evolution-led catalyst traits. The advent of designer biocatalysts, produced by informed selection and mutation through recombinant DNA technology, enables production of process-compatible enzymes. However, to fully realize the potential of designer enzymes in industrial applications, it will be necessary to tailor catalyst properties so that they are optimal not only for a given reaction but also in the context of the industrial process in which the enzyme is applied.
\end{abstract}

The past two decades have led to major advances in our understanding of the subtleties of protein structure-function interrelationships. Mechanisms of protein stability in aqueous and nonaqueous environments ${ }^{1,2}$, the links between conformational mobility, structural integrity and activity $^{3,4}$, and the complexities of substrate specificity have all succumbed to the onslaught of advanced molecular methods, including crystallography ${ }^{5-7}$, site-specific mutagenesis, gene shuffling, and protein evolution ${ }^{8-11}$. Scientists are now in a position to visualize, if not design, catalytic systems that approach the functional "ideal".

The "ideal" catalyst is typically considered by the biochemist in terms of turnover number $\left(\mathrm{k}_{\mathrm{cat}}\right)$ or, for a given process, in terms of maximum specificity constant $\left(\mathrm{A}_{\mathrm{cat}} / \mathrm{KM}\right)$. However, from a bioprocess viewpoint, each bioprocess is constrained by a set of conditions dictated by the specific properties of the substrates, products, and the bioconversion reaction. Thus, while for any given bioprocess it is clearly possible to specify a set of catalyst properties that would constitute the ideal for that process, only broad generalizations for ideality may otherwise be identified.

In this review, we discuss molecular properties of enzymes from a bioprocess viewpoint. A paradigm for design based on the ideal process determining the desired features of the catalyst is presented. "Ideal" characteristics (generic and process-specific) and methodologies for seeking or engineering these are discussed. We then review the extent to which significant changes in protein functional properties have been achieved by application of these methods, together with issues that require more research and/or development.

\section{Ideal processes}

Bioprocess engineers develop processes not only against fixed capital and operating expenditure, but also rapid, and often, very aggressive timelines. This is particularly the case for pharmaceutical products where patent expiry on the product demands a robust and scalable process with short development times ${ }^{12}$. Conventionally, once a synthetic route is fixed and the biocatalytic step defined, bioprocess design and operation are centered on the properties of the 
biocata-lyst. There are two reasons for this. First, biocatalysts are typically characterized by tight operational specifications. Second, the biocat-alyst can often represent a significant proportion of the process operating costs. Increasingly, with more expensive substrates and improved biocatalyst production this contributing proportion is being reduced, and with expansion of the range of suitable biocata-lysts, it may become desirable as well as possible to center bioprocess design and operation on the reaction properties, rather than the bio-catalyst (see Fig. 1). Thus, the conventional paradigm can be reversed and the biocatalyst can be designed to fit the process. This alternative approach leads us to ask: what are the ideal properties we would want of a "designer" biocatalyst, and how would we identify these ideal properties?

The flexibility to design the biocatalyst to fit the process still carries a number of catalystindependent constraints, set by the thermodynamics of the reaction and the properties of reactants and products (Table 1). In particular, the water solubility characteristics of the reactants and products determine the medium for operation ${ }^{13}$, and their stability as a function of $\mathrm{pH}$ and temperature determine the range in which the process must operate. In addition, high product concentrations are important in optimizing product recovery.

Under the ideal process paradigm (Fig. 1), preselection of optimal process conditions can supersede the constraints of any particular biocatalyst. A range of technologies contributes to the preselection process (Fig. 2). Having selected the "ideal" process conditions, a growing range of molecular technologies are available for identification or engineering of the "ideal" biocatalyst.

\section{Definitions}

$\mathbf{T}_{\mathrm{m}}$ Protein melting (denaturation) temperature, typically determined by physical methods such as fluorescence, circular dichroism (CD) or calorimetry.

$\mathbf{T}_{\text {opt }}$ Apparent temperature optimum for enzyme activity, for a defined set of reaction conditions. $\mathbf{k}_{\mathrm{cat}}$ Turnover number $=$ maximum number of substrate molecules converted to product per unit time per active site; a function of the rate constants for the conversion of enzyme-substrate complex to enzyme + product.

$\boldsymbol{K}_{\boldsymbol{M}}$ Michaelis constant, representative of the dissociation of the enzyme-substrate complex, taken as an indication of substrate binding to the active site.

$\boldsymbol{k}_{\boldsymbol{J}} \boldsymbol{J} \boldsymbol{K}_{\boldsymbol{M}}$ Specificity constant; indicates the rate of association of enzyme and substrate and also indicates specificity for competing substrates.

\section{Catalyst production}

The key to the process architecture defined in a particular case is whether the catalyst is to be used as a whole cell or an isolated enzyme. For the majority of enzyme-catalyzed reactions, use of an isolated (immobilized) enzyme is the ideal provided that isolation is simple. However, for membrane-bound and/or cofactor-dependent enzymes and/or those that are multiprotein 
complexes, isolation may not be possible, and here the alternative whole-cell process will prove the preferred option. It is beyond the scope of this review to consider in depth the presentation of the enzyme within a reaction system and the very important aspects of free versus cellencapsulated biocatalysts, but the reader is directed to a number of relevant publications ${ }^{14-16}$.

Whether a whole-cell or an isolated-enzyme biocatalyst is required, expression in a rapidly growing, robust host is the first requirement. Constitutive, rather than inducible, expression is preferred. High levels of expression will minimize the fermentation volume, but may lead to inclusion body formation. Developments in host-vector systems, coupled with highly evolved fermentation technologies, have resulted in bacterial and fungal fermentations capable of yielding recombinant enzymes at levels of upward of $10 \mathrm{~g} / \mathrm{L}$, in stark comparison with laboratory-based expression of recombinant enzymes, where yields of $10-100 \mathrm{mg} / \mathrm{L}$ are frequently reported. In all cases, the cost of media imposes a need to minimize fermentation volumes by high levels of expression. Protease activities, which can result in substantial loss of biocatalyst yield, also need to be minimized.

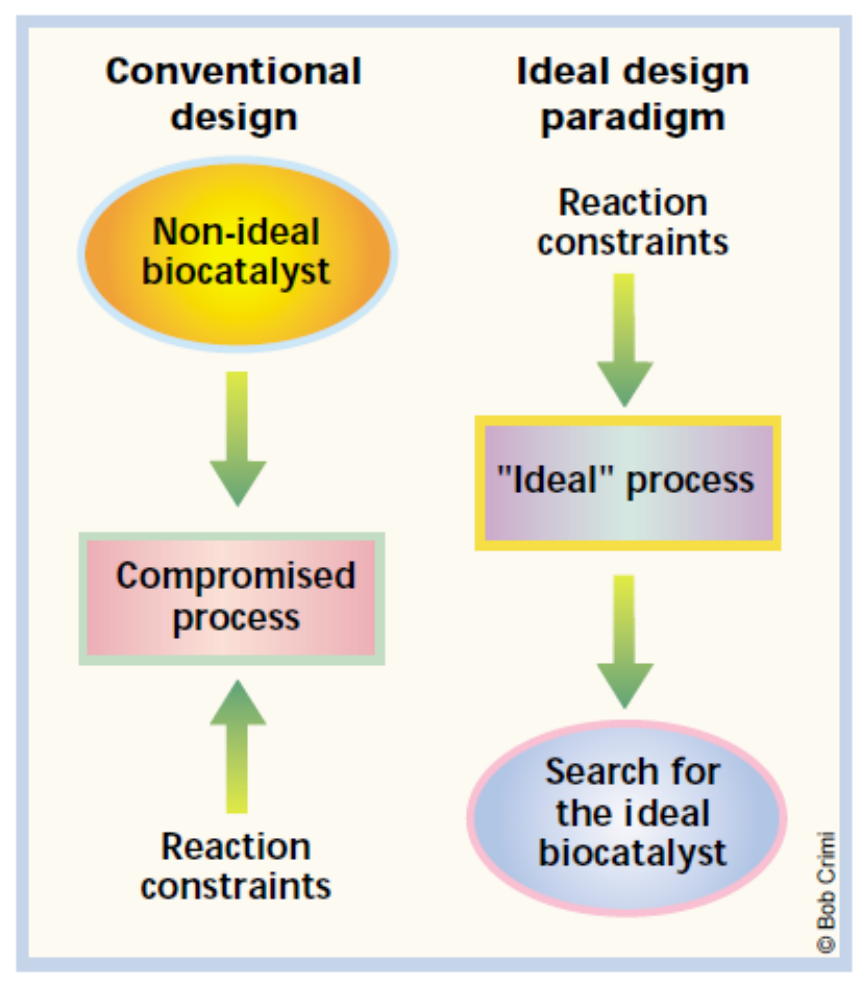

Figure 1. The paradigm shift? Traditionally, the characteristics of the enzyme have constrained the operational limits of the process. New approaches to enzyme discovery offer the prospect of designing the biocatalyst to suit the optimal parameters of the process.

\section{Reactors}

Ideal reactors are those with high space/time yield to reduce the capital costs. A packed bed of immobilized enzyme has clear advantages in that the voidage is low: $34 \%$ compared with up to 
over $80-90 \%$ for a stirred-tank reactor ${ }^{17}$. The hydrodynamics of a packed-bed reactor, characterized by plug flow, have a number of implications, particularly in the generation of concentration gradients of substrate and product. As a consequence, both low enzyme KM and substrate inhibition are critical, so as to capitalize on the concentration gradient generated from column input to output.

Similarly, $\mathrm{pH}$ adjustment is not possible during a single pass through a packed bed, so it is essential that the $\mathrm{pH} /$ activity profile for the enzyme is sufficiently broad to accommodate any $\mathrm{pH}$ changes. Critically, multiphasic mixtures cannot be handled in a packed bed, although a fluidized bed is a reasonable compromise (S. Beveridge etal., unpublished data).

Table 1. Constraints influencing the operating conditions of bioconversion processes
$\begin{aligned} & \text { Type of constraint } \\ & \text { Reaction-specific constraints dependent on the } \\ & \text { nature of reactants and products }\end{aligned}$
$\begin{aligned} & \text { Water solubility of reactants and products } \\ & \text { (which is dependent on pH and temperature) } \\ & \text { Stability of reactants and products }\end{aligned}$
$\begin{aligned} & \text { Chemical nature of reactants and products } \\ & \text { Production or consumption of gases }\end{aligned}$
$\begin{aligned} & \text { Production or consumption of acid or alkali } \\ & \text { Reaction equilibrium (which is in turn dependent } \\ & \text { on pH and temperature) }\end{aligned}$
$\begin{aligned} & \text { The pH range over which optimal activity and stability } \\ & \text { of biocatalyst can be maintained }\end{aligned}$
$\begin{aligned} & \text { Temperature range for biocatalyst optimal activity and stability } \\ & \text { Biocatalyst-specific constraints dependent on the } \\ & \text { evolved or modified properties of the biocatalyst } \\ & \text { tolerated by biocatalyst without inhibition or saturation effects }\end{aligned}$

\section{Product recovery}

The ideal process involves the minimum number of downstream steps. The catalyst must be easily recovered (immobilization by retention inside the packed bed is optimal). A bottleneck for many current processes is the large volume of water from which the product must be removed, necessitating a concentration step before isolation ${ }^{18}$.

In the ideal process, the catalyst would withstand concentrations of the product high enough to allow a single isolation step without prior product concentration.

\section{Key biocatalyst properties}

Turnover. Considering that the primary objective of any industrial biotransformation process is a high degree of substrate conversion to product in the minimum possible time, the turnover of an enzyme represents a key factor in the concept of the ideal biocatalyst. As many enzymes have evolved for very specific and selective metabolic roles, the intrinsic activity or turnover of native enzymes depends fundamentally on the nature and mechanism of the in vivo reaction catalyzed and the position of in vivo reaction equilibria with respect to metabolic flux. Thus, a particular enzyme may catalyze a desired bioconversion reaction, but with a $\mathrm{k}_{\mathrm{cat}}$ too low for practical application, in which case improvement of the turnover using the novel technologies now 


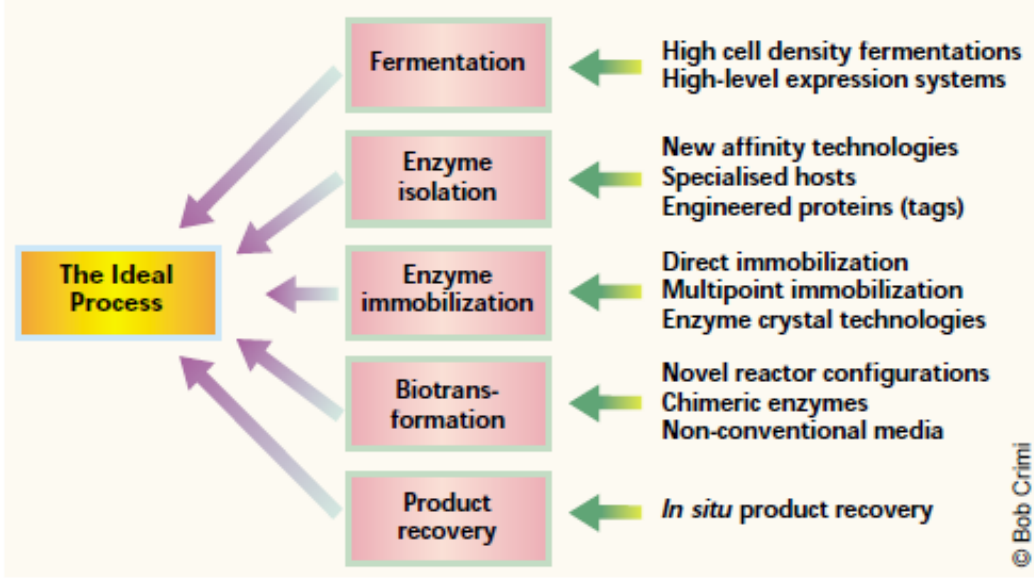

Figure 2. Contributions to the design of the ideal biotransformation process. Each unit operation can be enhanced by the development of key technologies. For example, high cell density fermentations lead to reduced fermentation volumes and simpler dewatering processes.

available (e.g., directed evolution, gene shuffling, and combinations of rational and combinatorial methods) may be required ${ }^{19}$. Although turnover characteristics of enzymes typically used in bioconversions vary widely, high turnovers are characteristic of most current commercial biocatalytic processes.

In an operational biocatalyst, the turnover may be influenced not only by the genetically determined functional capacity of the protein, but also by the microenvironment of the enzyme, and specifically by the form in which the biocatalyst is formulated and applied. Thus process conditions (e.g., the type and use of immobilized enzymes) have considerable influence over the maximum achievable turnover exhibited by the biocatalyst. Such chemical modifications frequently result in lowering of $\mathrm{k}_{\mathrm{cat}}$ values, attributed to a range of effects, including variations in protein flexibility and allosteric properties (conformational), decreased accessibility to the enzyme active $\operatorname{site}^{20}$ (steric), and changes in the enzyme microenvironment by the selective attraction or exclusion of water, ions, solutes, and so on ${ }^{21}$.

The operating temperature of a biocatalytic process is frequently dictated by factors relating to the reaction rather than the catalyst, such as substrate/product solubilities, reagent stabilities, or the need to reduce undesirable side reactions. Arrhenius kinetics suggest that the highest feasible reaction temperature should be selected, but such selection is always constrained by biocatalyst stability.

Fortunately, evolution has provided a relatively wide thermal range of native biocatalysts, and enzymes derived from psychrotolerant (cold-active) to hyperthermophilic microorganisms may retain high levels of activity and/or stability across a temperature range from below $10^{\circ} \mathrm{C}$ to 
around $100^{\circ} \mathrm{C}$, as demonstrated for a set of functionally homologous enzymes in Figure 3 . Where the reaction temperature is dictated by the process components, a priori selection of an enzyme from the appropriate thermal group (Fig. 3) may minimize subsequent requirements for enhancing either turnover or molecular stability.

The ideal biocatalyst for bioconversions involving organic and hydrophobic substrates would exhibit high turnover in organic or aqueous-organic media. Many enzymes remain active and stable in organic media, but relatively few exhibit enhanced turnover. Although research using native enzymes has provided insight into the effects of solvents and ionic conditions on enzyme activity $^{22,23}$ and control over reaction pathways ${ }^{24}$, biocatalysts with significantly improved turnover in organic solvent media have recently been developed (Table 2).

\begin{tabular}{|c|c|c|c|c|c|c|}
\hline \multirow[t]{2}{*}{ Enzyme and reaction condltions } & & \multicolumn{4}{|c|}{ KInetjc parameters reported } & \multirow[t]{2}{*}{ Comments } \\
\hline & & $V_{\max }$ & $k_{\text {eat }}$ & $K_{w}$ & $K_{\mathrm{cox}} / K_{\mathrm{m}}$ & \\
\hline \multirow{5}{*}{$\begin{array}{l}\text { Subsilisin E and mutants generated by } \\
\text { sequential random mutagenesis; ester } \\
\text { hydrolysis activity in presence of DMPs, }\end{array}$} & Nattve enzyme & & & & & \multirow{5}{*}{$\begin{array}{l}\text { Varlant shows Improved } K_{a x} \text { in DMF } \\
\text { as compared with aqueous medum, } \\
\text { and } K_{\alpha} / K_{v} \text { approaching that of native } \\
\text { enzyme in aqueous medlum }\end{array}$} \\
\hline & $\begin{array}{l}\text { Aqueous medlum } \\
40 \% \text { DMF }\end{array}$ & $\begin{array}{c}\text { NAb } \\
\text { NA }\end{array}$ & $\stackrel{21}{3.3}$ & $\begin{array}{c}0.56 \\
20.9\end{array}$ & ${ }_{0.16}^{38}$ & \\
\hline & Varlant PC3 & & & & & \\
\hline & Aqueous medlum & NA & 27 & 0.1 & 274 & \\
\hline & $40 \%$ DMF & NA & 62 & 2.96 & 21 & \\
\hline \multirow{3}{*}{$\begin{array}{l}\text { Subtilsin EPN' solublized by lon } \\
\text { palring, transesteriflcation of APEE: } \\
\text { and propanof }{ }^{2}\end{array}$} & \multirow{3}{*}{$\begin{array}{l}\text { Aqueous medlum } \\
\text { Solubilized enzyme in } \\
\text { octane medum } \\
\text { suspended enzyme } \\
\text { in octane }\end{array}$} & NA & NA & NA & 3,500 & \multirow{3}{*}{$\begin{array}{l}\text { Solubilization by lon pairing results in } \\
\text { catayytic effclency that is } 60 x \text { that } \\
\text { of the suspended enzyme and only } 10 x \\
\text { lower than In aqueous medum }\end{array}$} \\
\hline & & NA & NA & NA & 370 & \\
\hline & & NA & NA & NA & 0.6 & \\
\hline \multirow{2}{*}{$\begin{array}{l}\text { Rhizopus amhizus Ipase-catalyzed } \\
\text { esterfication of dodecanol and } \\
\text { decanolc acid" }\end{array}$} & $\begin{array}{l}\text { Water-saturated } \\
\text { dllsopropyl ether }\end{array}$ & 280 & NA & 430 & NA & \multirow{2}{*}{$\begin{array}{l}\text { Decreased } K_{\text {mand }} \text { animlar } V_{\text {max }} \text { were } \\
\text { reported in medlum with Increased } \\
\text { water activity in a hydrophobic solvent } \\
\text { system }\end{array}$} \\
\hline & Dry disopropyl ether & 240 & NA & 33 & NA & \\
\hline \multirow[t]{2}{*}{$\begin{array}{l}\text { Mushroom polyphenol oxidase } \\
\text { hydroxylation of p-cresol" }\end{array}$} & Aqueous solution & 350 & NA & 1.98 & NA & \multirow{2}{*}{$\begin{array}{l}\text { Improved tumover suggested to be due } \\
\text { to increased solubilty of products in } \\
\text { organic solvent }\end{array}$} \\
\hline & Chioroform medlum & 812 & NA & 24.8 & NA & \\
\hline \multirow{2}{*}{$\begin{array}{l}\text { Subtilsin Carisberg transestertication } \\
\text { of CBZ-alanyl ONPa in water- } \\
\text { saturated solvents"s }\end{array}$} & Tolvene & $0.083^{*}$ & NA & NA & NA & \multirow{2}{*}{$\begin{array}{l}\text { Significantly increased catalytlc } \\
\text { effclency In hexane was attrilouted to } \\
\text { substrate solvation effects }\end{array}$} \\
\hline & $\begin{array}{l}\text { Isopropylether } \\
\text { Hexane }\end{array}$ & $\begin{array}{l}0.96^{\circ} \\
4.36\end{array}$ & $\begin{array}{l}\text { NA } \\
\text { NA }\end{array}$ & $\begin{array}{l}\text { NA } \\
\text { NA }\end{array}$ & $\begin{array}{l}\text { NA } \\
\text { NA }\end{array}$ & \\
\hline \multirow{2}{*}{$\begin{array}{l}\text { Subtilsin lyophilized in presence of } \\
\text { Increasing proportions of KCFA } \\
\text { and applied in anilydrous hexane }\end{array}$} & $\begin{array}{l}\text { Enzyme lyophilized in } \\
\text { absence of } \mathrm{KCl}\end{array}$ & NA & 0.027 & 260 & 0.104 & \multirow{6}{*}{$\begin{array}{l}\text { Salt-induced actvation of enzymes is } \\
\text { altributed to protection of the enzyme } \\
\text { from solvent deactivation, retention of } \\
\text { the active site structure, and retention } \\
\text { of water in the enzyme structure }\end{array}$} \\
\hline & $\begin{array}{l}\text { Enzyme lyophilized In } \\
\text { presence of } 98 \% \mathrm{KCl}\end{array}$ & NA & 10.04 & 26.7 & 390 & \\
\hline \multirow[t]{2}{*}{$\begin{array}{l}\alpha \text {-Chymotrypsin lyophilized in presence } \\
\text { of increasing proportions of KC:S4 }\end{array}$} & $\begin{array}{l}\text { Enzyme lyophilized in } \\
\text { absence of } \mathrm{KCl}\end{array}$ & NA & $4 \times 10^{-4}$ & 33 & 0.013 & \\
\hline & $\begin{array}{l}\text { Enzyme lyophilized in } \\
\text { presence of } 98 \% \mathrm{KCl}\end{array}$ & NA & $220 \times 10^{-4}$ & 33 & 0.67 & \\
\hline \multirow{2}{*}{$\begin{array}{l}\text { Subtilsin transesterifcation of APEE } \\
\text { in presence and absence of salts, } \\
\text { in hexane medlum preparation }\end{array}$} & $\begin{array}{l}\text { Salt-free enzyme } \\
\text { medlumps }\end{array}$ & NA & 0.0069 & 8.18 & 0.84 & \\
\hline & $\begin{array}{l}\text { Enzyme prepared by } \\
\text { lyophlization with } 98 \% \\
\text { KC. }\end{array}$ & NA & 2.16 & 2.24 & 966 & \\
\hline
\end{tabular}

Aobrevistona: APEE, acetyl pheynl alanyl ethyl eater, DMF, dmethyltormamide; ONP, o-niltrophenol.

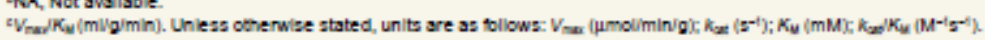


Selectivity. Substrate selectivity and affinity are evolved properties of an enzyme, related specifically to its metabolic role. For instance, the substrate range for highly specialized mammalian enzymes may be far narrower than that of extracellular fungal enzymes. In certain cases, broad substrate specificity is essential, as in the use of prote-olytic and lipolytic enzymes in laundry detergents, whereas in the production of most pharmaceuticals and fine chemicals, strict substrate selectivity is required to ensure fidelity in the reaction pathway, and viable conversion yields.

Control and optimization of stereoselectivity in synthetic bio-transformations and chiral resolutions have been seminal focus areas in biocatalysis in recent years, largely as a result of the inefficiency of conventional methods for stereochemical control. Many highly stereoselective biocatalysts are already in large-scale industrial use (see Table 3), and novel moleone reaction type to another, for example, in the modification of indole-3-glycerophosphate synthase, by a combination of rational design and directed evolution, to produce novel phosphoribosyl anthranilate isomerase activity ${ }^{25}$. Substrate selectivity can readily be altered, using molecular or reaction engineering methods, to the extent where compounds of very different steric structure and chemical nature from the natural substrates can be efficiently converted by the biocatalyst . For instance, the D-selectivity of a native hydan-toinase was reversed by mutagenesis and selective screening procedures, giving an L-specific enzyme with no equivalent in nature, able to catalyze the production of L-methionine ${ }^{26}$. Gene-shuffling techniques have been used to randomly recombine genes from two organisms possessing biphenyl dioxygenase activity, yielding a recombinant enzyme capable of oxidative degradation of polychlori-nated biphenyls (PCBs) and simple aromatic monomers ${ }^{27}$.

Molecular stability. Biocatalyst stability is a major concern in virtually all bioprocesses, because it may affect process economics at a number of levels. Poor biocatalyst stability will result in longer process operations (resulting from decreasing catalytic efficiency), increased frequency of catalyst replacement and reduced product yields. The causes of reduced biocatalyst stability are intimately associated with the process conditions, and may include extremes of temperature, ionic strength, or $\mathrm{pH}$ that are outside the operating "stability window" of the catalyst, or the presence of denaturants, such as substrates/products, organic solvents, surfaces, or interfaces. Some of the options currently available to the bioprocess industry to address the problem of biocatalyst stability are summarized in Table 1 .

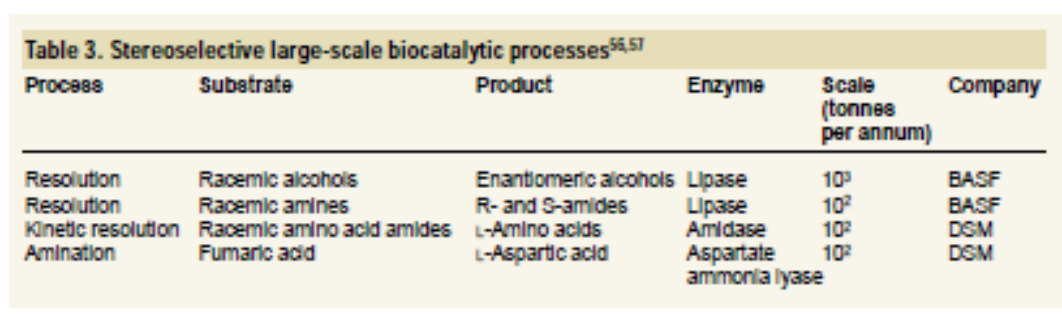


The effect of any deleterious condition on the lifespan of a biocat-alyst is dependent first on the intrinsic molecular stability of the protein, and second on the mode of presentation of the enzyme in the reactor system (e.g., whether the enzyme is cell-encapsulated, immobilized, or crosslinked). Intrinsic molecular stability is a function of both amino acid sequence and tertiary (and quaternary) structure and is dictated, at least in part, by the origins of the protein. Studies of extremophilic organisms and their enzymes have provided extensive insights into both the outer limits of molecular stability and molecular mechanisms responsible for structural stabilization. Proteins of extremely high thermal stability (e.g., Tm values of $80^{\circ}-130^{\circ} \mathrm{C}$ ) are typically isolated from hyperthermophilic organisms (growing at up to $115^{\circ} \mathrm{C}$ ), whereas the proteins of psychrophilic organisms (growing to well below $0^{\circ} \mathrm{C}$ ) are generally relatively unstable (e.g., $\mathrm{T}_{\mathrm{m}}$ values of $20^{\circ}-50^{\circ} \mathrm{C}$ ). While the selection of a hyperther-mophile-derived biocatalyst provides a ready means of ensuring high molecular stability, such enzymes have evolved to function optimally at near the organism's growth temperature and exhibit reduced catalytic rates if employed at lower temperatures (see Fig. 3).

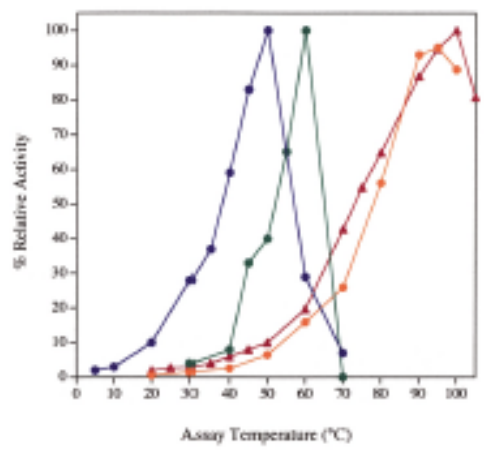

Figure 3. Temperature/activity profles for caseinolytic activities of extracellular proteases from different thermal sources. Psychrophillc (Xanthomonas maltophlla, $20^{\circ} \mathrm{C}(\bullet)$, mesophillic (Halomonas spp., $37^{*} \mathrm{C}$ (๑) extremely thermophlilic (Thermus aquaticus, $72^{\circ} \mathrm{C}(0)$ and hyperthermophillic (Desulurococcus mobllls, $88^{\circ} \mathrm{C}$ ( $(\Lambda)$. Data redrawn from refs $75-78$, respectively.

Over two decades of intensive study into the mechanisms of protein stability have led both to the identification of a range of molecular stabilization mechanisms (e.g., the presence of saltbridging networks: see reviews ${ }^{28-30}$ ) and to the engineering of increased structural stability by random and site-specific mutagenesis, enzyme evolution, and gene shuffling. While small increments in enzyme stability are typically achieved by site-specific mutagenesis ${ }^{31}$, some remarkable increases $\left(\mathrm{T}_{\mathrm{m}}\right.$ values enhanced by $10^{\circ}-15^{\circ} \mathrm{C}$ ) have been achieved by directed enzyme evolution $^{32,33}$. Such changes are not always to the detriment of catalytic activity. For example, the engineering of a 340 -fold increase in stability at $100^{\circ} \mathrm{C}$ in a Bacillus stearothermophilus protease by eight site-specific mutations ${ }^{34}$ was achieved without compromising catalytic activity, contradicting the dogma that molecular stability and activity are reciprocally related (through global conformational flexibility). Furthermore, there is good evidence for a general correlation between molecular stability to temperature and to other denaturing conditions ${ }^{35,36}$, suggesting common initiators and/or pathways of protein denaturation, whether induced by high 


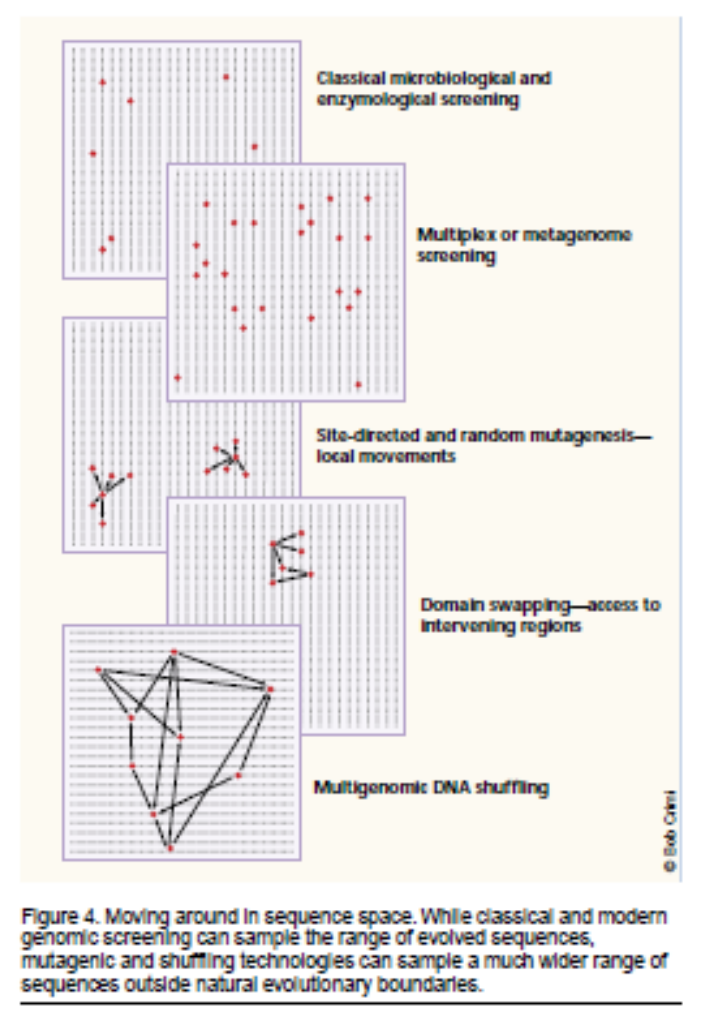

temperature, extremes of $\mathrm{pH}$, or the presence of organic solvents or detergents. The practical consequence of this observation is that the selection of a more thermostable enzyme variant (e.g., derived from a thermophilic source) or the engineering of enhanced thermostabil-ity may also result in increased molecular resistance to a range of deleterious conditions.

Virtually all the industrially significant changes in catalyst stability (e.g., in the evolution of xylose isomerases in the glucose conversion/high-fructose syrup industry) have come from strain selection, chemical modification (immobilization, chemical crosslinking), classical mutagenesis, or random mutagenesis. Of these, chemical modification is still the most widely used technology in industry for increasing biocatalyst stability. This preoccupation with traditional technology may reflect the simplicity and reliability of the procedures, and their cost-effectiveness in comparison with more modern and sophisticated genetic technologies. Recent developments in immobilization and related technologies, including cell-surface expression of enzymes ${ }^{37,38}$, multipoint covalent immobilization ${ }^{39}$, and the application of crosslinked enzyme crystals ${ }^{40}$, are likely to ensure that industrial biocatalysis continues to employ such methods. The last two of these methods take advantage of the fact that a restriction of conformational flexibility, as in covalent crosslinking or embedding in a crystal lattice, significantly increases the activation energy of denaturation and prevents enzyme aggregation. 


\begin{tabular}{|c|c|c|c|}
\hline Target Improvement & Technology avallable & Example & Activity enhancement \\
\hline \multirow[t]{5}{*}{ Increased turnover } & Solublization of enzyme & $\begin{array}{l}\text { Solubilization of subtillsin } \\
\text { (Using Isooctane }+A O T \cdot \text { ') for } \\
\text { application in organic solvents }\end{array}$ & $\begin{array}{l}\text { Specificity constant } K_{\infty} / K_{m} \text { of solubillzed } \\
\text { subtilsin in octane }-10^{5} \times \text { that of suspended } \\
\text { enzyme, and } 0.1 \times \text { that in aqueous medlum, } \\
\text { stablity in octane } 10^{3} x>\text { in aqueous medlum? }\end{array}$ \\
\hline & & $\begin{array}{l}\text { Blocatalyst plastics using } \\
\text { chymotrypsin and subtllisin }\end{array}$ & $\begin{array}{l}\text { Incorporaton of chymotrypsin and subtllsin in } \\
\text { synthetic polymers gave } 10^{4} \times \text { increased reaction } \\
\text { rates with high stability, in polar solvents, } \\
\text { facilitating efficlent peptide synthesis: }\end{array}$ \\
\hline & & $\begin{array}{l}\text { Solubilization of chymotrypsin } \\
\text { and subtllsin for use in organic } \\
\text { solvents using propanol rinsing } \\
\text { treatment }\end{array}$ & $\begin{array}{l}\text { Activity of chymotrypsin and subtllsin } \\
\text { Carisberg } 10^{5} \text { greater than freeze-dried powder } \\
\text { and comparable wth CLEC preparationss }\end{array}$ \\
\hline & Molecular imprinting & $\begin{array}{l}\text { Imprinting of subtlisin } \\
\text { (Carisoerg and mutants) with } \\
\text { sucrose, thymidine, and other } \\
\text { nuclecsides }\end{array}$ & 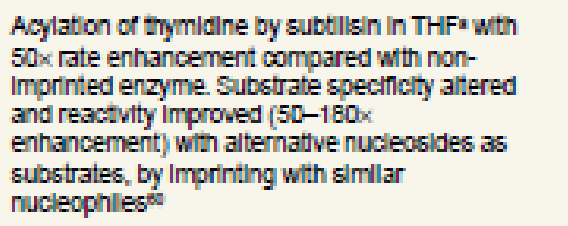 \\
\hline & & $\begin{array}{l}\text { Induction of enzyme activity by } \\
\text { lyophlization of papain and } \\
\text { lactoglobulin In presence of } \\
\text { transition-state analog }\end{array}$ & $\begin{array}{l}\text { Papain and lactoglobulin imprinted with a } \\
\text { transition-state analog showed activity in } \\
\text { the catalysis of } \beta \text {-elmination reactions } 3 \times \text { higher } \\
\text { than nonimprinted protein" }\end{array}$ \\
\hline \multirow[t]{3}{*}{$\begin{array}{l}\text { Altered } \\
\text { enantioselectivity }\end{array}$} & Directed evolution & $\begin{array}{l}\text { Improved enantioselectuvty in } \\
\text { Ilpases }\end{array}$ & $\begin{array}{l}\text { Pseudomonas aenuginosa Ipase actulty with } \\
\text { Improved S-enantloselectlvity, } 2 \% \text { ee increased } \\
\text { to } 81 \% \text { ee afer four generations of mutants } 5^{n 2}\end{array}$ \\
\hline & & $\begin{array}{l}\text { Reversed hydantoinase } \\
\text { enantloselectivity }\end{array}$ & $\begin{array}{l}\text { Conversion of o- to L-selectivity with fivefold } \\
\text { Increase in total activity, in Arthrobacter sp. } \\
\text { hydantolnase used for production of } \\
\text { L-methionine. No natural L-specific hydantolnase } \\
\text { is known?s }\end{array}$ \\
\hline & & $\begin{array}{l}\text { Improved enantioselectivity in } \\
\text { esterase-catalyzed } \\
\text { stereoselective resolution }\end{array}$ & $\begin{array}{l}\text { Esterase from Pseudomonas fuorescens in E coll } \\
\text { mutants selected to hydrolyze bulky } \\
\text { 3-hydroxyesters, giving } 25 \% \text { ee (ref. } 63 \text { ) }\end{array}$ \\
\hline \multirow[t]{3}{*}{ Aitered functionality } & $\begin{array}{l}\text { Rational design and } \\
\text { drected evolution }\end{array}$ & New isomerase actlvity evolved & 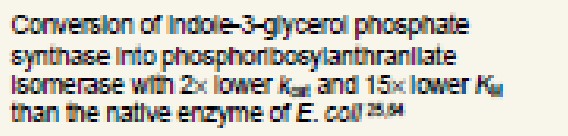 \\
\hline & Rational design & $\begin{array}{l}\text { Desaturase altered to } \\
\text { mydroxylase }\end{array}$ & $\begin{array}{l}\text { Change of activity from double-bond insertion to } \\
\text { hydroxylation in oleate desaturase, by site- } \\
\text { drected mutagenesis at seven slites, selected by } \\
\text { comparative analysis of amino acid sequences of } \\
\text { oleate desaturases and unrelated hydraxylases"s }\end{array}$ \\
\hline & $\begin{array}{l}\text { Gene shuming and } \\
\text { screening }\end{array}$ & $\begin{array}{l}\text { Modined } \beta \text {-galactosidase } \\
\text { activity }\end{array}$ & $\begin{array}{l}\text { DNA shuming gave an evolved } \beta \text {-galactosidase } \\
\text { with } 10 \text {-fold increased fucosidase and } 40 \text {-fold less } \\
\text { galactosidase activity, due to six amino acld } \\
\text { changes* }\end{array}$ \\
\hline $\begin{array}{l}\text { Conversion of non- } \\
\text { natural substrates }\end{array}$ & $\begin{array}{l}\text { Directed evolution } \\
\text { specincity }\end{array}$ & Recombination to alter substrate & 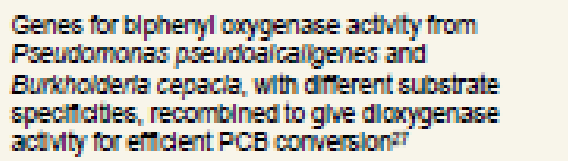 \\
\hline $\begin{array}{l}\text { Increased enzyme } \\
\text { stability }\end{array}$ & Directed evolution & $\begin{array}{l}\text { Thermostable esterase developed } \\
\text { by directed evolution }\end{array}$ & $\begin{array}{l}\text { Improved thermostability ( }>14^{*} \mathrm{C} \text { increase in } T_{m} \\
\text { atter stx cycles of mutation) without loss of } \\
\text { activity, showing that the two propertles are not } \\
\text { mutualy exclusive" }\end{array}$ \\
\hline
\end{tabular}




\begin{tabular}{|c|c|c|c|}
\hline Target Improvement & Technology avallable & Example & Acttvity enhancement \\
\hline & & $\begin{array}{l}\text { Increased thermostablity of } \\
\text { subtllisin } \mathrm{E}\end{array}$ & $\begin{array}{l}\text { Subtlisin was altered by elght amino acid } \\
\text { substitutions, to give functional Thermitase using } \\
\text { PCR mulagenesis and staggered extension } \\
\text { process recombination'? }\end{array}$ \\
\hline & $\begin{array}{l}\text { Genetic and rational } \\
\text { approach }\end{array}$ & $\begin{array}{l}\text { Increased thermostablity in a } \\
\text { protease }\end{array}$ & $\begin{array}{l}\text { Protease activity with half-life } 170 \mathrm{~min} \\
\text { (ct. } 1 \text { min In nattve encyme) at } 100^{\circ} \mathrm{C} \text {, in the } \\
\text { presence of denaturants, and widd-type level of } \\
\text { actulty, in elghtfold mutant of thermolysin-like } \\
\text { protease from Baclilus stearothermophius }\end{array}$ \\
\hline $\begin{array}{l}\text { Increased stability } \\
\text { and activity }\end{array}$ & Cell-surtace expression & $\begin{array}{l}\text { Functional display of } \\
\text { levansucrase activity on } \\
\text { cell surtace of } E \text {. coll }\end{array}$ & $\begin{array}{l}\text { Levansucrase activity of Zymomonas mobills } \\
\text { co-expressed and anchored with ice-nucleation } \\
\text { actuty in conversion of proteln from } \\
\text { Pseudomonas syingae gave high sucrose to } \\
\text { gucose and resistance to protease"u }\end{array}$ \\
\hline \multirow[t]{4}{*}{$\begin{array}{l}\text { Chemical } \\
\text { modification to } \\
\text { Increase stablity }\end{array}$} & $\begin{array}{l}\text { Covalent } \\
\text { Immobilization- } \\
\text { multipoint attachment }\end{array}$ & $\begin{array}{l}\text { Hyperstabilization of a } \\
\text { thermophllic esterase }\end{array}$ & $\begin{array}{l}\text { Thermophilic esterase from Bacilus } \\
\text { stearothemophlis modifed to glve } 3 \times 10^{s} \\
\text { Increased thermostability, compared with native } \\
\text { enzyme, by multipoint covalent immobllzation } \\
\text { through amino groups ilinked to glyoxyl agaroses }\end{array}$ \\
\hline & Chemical crossilinking & $\begin{array}{l}\text { Use of dextran dlaldehyde for } \\
\text { crosslinking }\end{array}$ & $\begin{array}{l}\text { Stabilization of } E \text {. coll penicillin } G \text { acylase } \\
\text { against thermal inactivation by crossilining with } \\
\text { dextran dlaidehyde polymers. Modilned enzyme } \\
\text { showed ninefoid increase in hali-life of Inactivation } \\
\text { at } 55^{\circ} \mathrm{C} \text { and no decrease in } V_{\mathrm{ma}} \text { (ret. } 69 \text { ) }\end{array}$ \\
\hline & CLEC formation & $\begin{array}{l}\text { Crossiniking and chemical } \\
\text { modifcaton of subtlisin }\end{array}$ & $\begin{array}{l}\text { Subtilisin crystallized, crossilnked, and } \\
\text { chemically converted to glve peroxidase activity } \\
\text { with higher stablity }(10 x) \text { without loss of } \\
\text { enantioselectlvityro }\end{array}$ \\
\hline & $\begin{array}{l}\text { Upid coating of } \\
\text { enzymes }\end{array}$ & $\begin{array}{l}\text { Application of gycoside } \\
\text { hydrolases in organic medlum }\end{array}$ & $\begin{array}{l}\text { Upid coatings on mannosidase, glucosidase, and } \\
\text { giucosaminidase gave hydrophobic nature to } \\
\text { enzyme surfaces and increased (80\% } \mathrm{c} .10 \% \text { ) } \\
\text { transglycosylation actuty in } \mid \text { isopropyl ether } 71\end{array}$ \\
\hline $\begin{array}{l}\text { Chemical modification } \\
\text { to increase activity }\end{array}$ & $\begin{array}{l}\text { Modincation with } \\
\text { monofunctonal } \\
\text { reagents }\end{array}$ & $\begin{array}{l}\text { Modifcaton of catalase with } \\
\text { Bri] } 35 \text { surfactant }\end{array}$ & $\begin{array}{l}\text { Catal ase activity increased } 200 \times \text { in } \\
\text { trichioroethylene and } 15 \times \text { in aqueous medum, } \\
\text { compared with native enzyme? }\end{array}$ \\
\hline $\begin{array}{l}\text { Modined reaction } \\
\text { milleu }\end{array}$ & Directed evolution & $\begin{array}{l}\text { Increased esterase actlvity in } \\
\text { aqueous/organic medlum }\end{array}$ & $\begin{array}{l}\text { p-Nitrobenzyl esterase activity of subtlisin in } \\
30 \% \text { DMF increased } 50 \times \text { using random } \\
\text { mutagenesis }\end{array}$ \\
\hline
\end{tabular}

"Abbreviatons: AOT, Aerosol OT; CLEC, crosalinked enzyme crystat; ee, enantiomeric excesa

\section{Catalyst diversity}

Whether a process is designed around the catalyst properties, or the catalyst is selected to suit process needs, the available range of relevant catalysts is a key issue. The range of enzymes potentially available to the bioprocess industry is firstly dictated by evolution, that is, by genetic diversity. Although little consensus exists on true genetic diversity (genetic represented as species diversity), estimates for plant, animal, and microbial diversity (see Table 5) are in the order of $10^{7}-10^{8}$ species. With an average of $10^{4}-10^{5}$ open reading frames per genome, many of which encode enzymes, the total enzyme genetic diversity may be as great as $10^{13}$ distinct functional sequences. This figure is, of course, substantially reduced by the varying, often high, homology between enzymes from related and even unrelated organisms.

This diversity of closely, distantly, or unrelated sequences represents the core biological resource, conceptually considered in terms of "sequence space" ${ }^{41}$. Native sequence space, representing the 
diversity of functional (and nonfunctional) protein sequences available from nature, still represents a relatively small proportion of total sequence space-theoretically estimated as the total number of permutations of 20 amino acids (which is $20^{100}$ for a polypeptide of 100 amino acids). Only a relatively small proportion of native sequence space is currently available to the scientific and bioindustrial community, for the simple reason that a very high proportion of extant species have never been investigated, or, even if investigated, are not readily accessible. The acknowledged reality that a very high proportion of microbial species are currently "unculturable" 42 (Table 5) further restricts access to microbial (bacterial, archaeal, fungal, and unicellular algal) genomes and gene products.

The rapid development of genetic technologies has provided increasingly inventive methods for indirectly accessing new areas of sequence space (Fig. 4). Chemical, site-directed, and random muta-genesis technologies access regions proximal to the native sequences, whereas methods, such as gene and domain swapping, DNA shuffling, and other forms of combinatorial genomics access the regions between the parent sequences.

Modern bioprospecting methods such as multiplex or metagenome cloning ${ }^{43-46}$ and similar methods used by companies such as Diversa Corporation (La Jolla, CA) and TerraGen Discovery (Vancouver, BC, Canada) directly access environmental genomes (whether culturable or unculturable). These methods access sequence space in a virtually random manner and have been successfully employed to isolate novel nabR (ref. 45) and amylase, lipase, and hemolytic enzyme genes ${ }^{46}$.

\section{Perspective}

If we accept the new paradigm that the design of an optimized process may proceed without intimate consideration of the limitations of the biocatalyst, and that technologies are available for the subsequent selection or design of the "ideal" catalyst, the following questions are highly relevant: First, where are the limiting factors? And second, what more is required to overcome the limiting factors?

It is evident from the recent literature that in vitro enzyme evolution technologies are being very rapidly assimilated. These offer a relatively fast and inexpensive approach to the incremental modification of selected enzyme properties, with a reduced risk that desirable enzyme characteristics will be lost in the process.

A major limitation is the monoselective nature of almost all protein-engineering and enzymescreening technologies. Single-function screening is essentially incompatible with the requirements of the "ideal process" paradigm, in which a defined set of target properties will require polyfunctional screening and/or engineering strategies. First attempts at multifunction screening have been reported ${ }^{47}$. 
However, despite the recent development of sophisticated molecular engineering and screening technologies, our ability to move around sequence space in search of the ideal catalyst for a given

\begin{tabular}{|c|c|c|}
\hline Group of organlams & $\begin{array}{l}\text { Eatimated } \\
\text { spoctas }\end{array}$ & $\begin{array}{l}\text { Accoselble } \\
\text { (known) specles } \\
\text { (as } \% \text { of total) }\end{array}$ \\
\hline Anlmals (imammals, blrds, flehes) & $3.5 \times 10^{4}$ & -90 \\
\hline Arthropodsinuertebrates & $10^{s}-10^{r}$ & 10 \\
\hline Nematodes & $5 \times 10^{3}$ & 3 \\
\hline Higher plants & $27 \times 10^{3}$ & -90 \\
\hline Algae & $10^{4}-10^{8}$ & [70] \\
\hline Eryophytes & $25 \times 10^{4}$ & $70^{\circ}$ \\
\hline Fungli & $1.5 \times 10^{3}$ & [5] \\
\hline Bacterla' & $10^{4}-10^{*}$ & [1-107s] \\
\hline Archaea: & $10^{4}-10$ & {$[0.1-1 \%]$} \\
\hline Vuses: & $10^{3}-10^{3}$ & {$[4]$} \\
\hline
\end{tabular}

process is still limited. Rational design methods face the greatest limitation in scope. For example, despite the intense focus over the past decade on the molecular determinants of protein stability, site-specific protein engineering cannot yet be reliably applied to protein stabilization. None of the "design rules" for thermostability that have evolved from comparative structural studies of more and less stable protein homologs ${ }^{44,48}$ can be simply employed to indicate sitespecific modifications for reliably enhancing molecular stability. The use of design algorithms for predicting multiple additive muta-tions ${ }^{49}$ may provide a future guide to the engineering of hyperther-mostable enzymes. Such algorithms are not currently available for other functional characteristics (solvent stability, alterations in specificity, $\mathrm{pH}$ behavior, or turnover, for example) for which even less generic molecular information is available. Direct (i.e., metage-nomic) screening and DNA-shuffling technologies offer the widest access to sequence space. However, both are limited by the fact that any single environmental DNA sample is a poor representation of the enormous genomic diversity present in the multitude of global biotopes.

So are we ready to implement the ideal process paradigm? We conclude that many of the necessary molecular and screening technologies are in place, and there is early evidence of an evolution from monofunctional to multifunctional screening. In our opinion, the full implementation of the latter is the key to the successful acquisition of new "designer" biocatalysts for truly optimized "ideal" bio-processes. 


\section{References}

1. Halling, P.J. Biocatalysis in low-water media: understanding effects of reaction conditions. Curr. Opin. Chem. Biol. 4, 74-80 (2000).

2. Wangikar, P.P, Michels, Clark, D.S. \& Dordick, J.S. Structure and function of subtilisin BPN solubilized in organic solvents. J. Am. Chem. Soc. 119, 70-76 (1997).

3. Kazlauskas, R.J. Molecular modelling and biocatalysis: explanations, predictions, limitations and opportunities. Curr. Opin. Chem. Biol. 4, 81-88 (2000).

4. Selleck, G.A. \& Chaudhuri, J. B. Biocatalysis in organic media using enzymes from extremophiles. Enzyme Microb. Technol. 25, 471-482 (1999).

5. Schmitke, J.L., Stern, L.J. \& Klibanov, A.M. The crystal structure of subtilisin Carlsberg in anhydrous dioxane and its comparison with those in water and ace-tonitrile. Proc. Natl. Acad. Sci. USA 94, 4250-4255 (1997).

6. Aguilar, C.F et al. Crystal structure of the p-galactosidase from the hyperther-mophilic archaeon Sulfolobus solfaricus: resilience as a key factor in thermosta-bility. J. Mol. Biol. 271, 789-802 (1997).

7. Villeret, V. et al. The crystal structure of Pyrococcus furiosus ornithine carbamoyltransferase reveals a key role for oligomerisation in enzyme stability at extremely high temperatures. Proc. Natl. Acad. Sci. USA 95, 2801-2806 (1998).

8. Martin A.B. \& Schulze, P.G. Opportunities at the interface of chemistry and biology. Trends Biochem. Sci.. 24, M24-M28 (1999).

9. Arnold, F.H. \& Volkov, A.A. Directed evolution of biocatalysts. Curr. Opin. Chem. Biol. 3, 54-59 (1999).

10. Arnold, FH. Design by directed evolution. Acc. Chem Res. 31, 125-131 (1998).

11. Affholter, J. \& Arnold, F.H. Engineering a revolution. Chem Tech. 26, 34-39 (1999).

12. Tapolczay, D.J., Kobylecki, R.J., Payne, L.J. \& Hall, B. Extracting order from chaos.Chem. Ind. 19, 772-775 (1998).

13. Woodley, J.M. \& Lilly, M.D. Process engineering of two-liquid phase biocatalysis.Prog. Biotechnol. 8, 147-154 (1992).

14. Wandrey, C., Liese, A. \& Kihumbu, D. Industrial biocatalysis: past, present and future. Org. Process Res. Dev. 4, 286-290 (2000).

15. Flitsch, S.L., Aitken, S.J., Cho, C.S.Y., Grogan, G. \& Staines, A. Biohydroxylation reactions catalysed by enzymes and whole-cell systems. Bioorg. Chem. 27, 8190 (1999).

16. Sette, L., Lanzarini, G. \& Pifferi, P.G. Whole cell biocataysis for an oil desulphur-ization process. Fuel Process. Technol. 52, 145-153 (1997).

17. Woodley, J.M. \& Lilly, M.D. Biotransformation reactor selection and operation. In Applied biocatalysis. (eds Cabral, J.M.S., Best, D., Boross L. \& Tramper J.) 371-393 (Harwood Academic, London; 1994).

18. Chauhan, R.P. \& Woodley, J.M. Increasing the productivity of bioconversion processes. Chem Tech 27, 26-30 (1997)

19. Shanklin, J. Exploring the possibilities presented by protein engineering. Curr. Opin. Plant Biol. 3, 243-248 (2000) 
20. Tischer, W \& Kasche, V. Immobilised enzymes: crystals or carriers? Trends Biotechnol. 17, 326-335 (1999).

21. Adlercreutz, P. On the importance of the support material for enzymatic synthesis in organic media-support effects at controlled water activity. Eur. J. Biochem.199, 609-614 (1991).

22. Kim, J. \& Dordick, J.S. Unusual salt and solvent tolerance of a protease from an extreme halophile. Biotechnol. Bioeng. 55, 471-479 (1997).

23. Toba, S. \& Mez, K.M. The concept of solvent compatibility and its impact on protein stability and activity enhancement in non-aqueous solvents. J. Am. Chem. Soc. 118, 99399948 (1997)

24. Jaeger, K.-E. \& Reetz, M.T. Directed evolution of enantioselective enzymes for organic chemistry. Curr. Opin. Chem. Biol. 4, 68-73 (2000).

25. Altamirano, MM, Blackburn, J.M., Aguayo, C. \& Fersht, AR. Directed evolution of a new catalytic activity using alpha/beta barrel scaffold. Nature 403, 617-622 (2000).

26. May, O., Nguyen, P.T., \& Arnold, F.H. Inverting enantioselectivity and increasing total activity of a key enzyme in a multi-enzyme synthesis creates a viable process for production of L-methionine. Nat. Biotechnol. 18, 317-320 (2000).

27. Kumamaru, T., Suenaga, H., Watanabe, T. \& Furukawa, K. Enhanced degradation of polychlorinated biphenyls by directed evolution of biphenyl dioxygenase. Nat Biotechnol. 16, 663-666 \{1998).

28. Hough, D. \& Danson, M.J. Extremozymes. Curr. Opin. Chem. Biol. 3, $39-36$ (1999).

29. Daniel, RM \& Cowan, D.A. Biomolecular stability and life at high temperatures. Cell. Mot. Life Sci. 57, 250-264 (2000)

30. Jaenicke, R. \& Bohm, G. The stability of proteins in extreme environments. Curr. Opin. Struct. Biol. 8, 738-748 (1998).

31. Lee, B. \& Vasmatzis, G. Stabilization of protein structures. Curr. Opin. Biotechnol.. 8,423428(1999).

32. Kuchner, O. \& Arnold. F.H. Directed evolution of enzyme catalysts. Trends Biotechnol. 15, 523-530 (1997).

33. Giver, L, Gershenson, A, Freskard, RO. \& Arnold, F.H. Directed evolution of a thermostable esterase. Proc. Natl. Acad. Sci. USA 95,12809-12813 (1998).

34. Van den Burg, B., Vriend, G., Venema, O.R. \& Eijsink, V.G. Engineering an enzyme to resist boiling. Proc. Natl. Acad. Sci. USA 95,2056-2060 (1998).

35. Daniel, R.M., Cowan, D.A., Curran, M. \& Morgan, H.W. A correlation between protein thermostability and susceptibility to proteolysis. Biochem. J. 207, 641-644 (1982).

36. Owusu, R.K. \& Cowan, D.A. A correlation between microbial protein thermostability and resistance to denaturation in aqueous-organic solvent two-phase systems. En\%: Microb. Technol. 11, 568-574 (1989).

37. Richins, R.D., Kaneva, I., Mulchandari, A., \& Chen, W. Biodegradation of organophosphorus pesticides by surface-expressed organophosphorus hydrolase. Nat Biotechnol. 15, 984-987 (1997). 
38. Jung, H.C., Lebeault J.M. \& Pan, J.G. Surface display of Zymomonas mobilis lev-ansucrase by using ice-nucleation protein of Pseudomonas syringae. Nat. Biotechnol. 16, 576-580 (1998).

39. Blanco, R.M. \&, Guisan, J.M. Stabilization of enzymes by multipoint covalent attachment to agarose aldehyde gels-borohydride reduction of trypsin agarose derivatives. Enz: Microb. Technol. 11, 360-366 (1989).

40. Hanng, D. \& Schreier, P Cross-linked enzyme crystals. Curr. Opin. Chem. Biol. 3, 35-38 (1999).

41. Stemmer, W.PC. Searching sequence space — using recombination to search more efficiently and thoroughly instead of making bigger combinatorial libraries. Bio/Technol. 13. 549-553 (1995).

42. Amann, R.I., Ludwig, W. \& Schleiffer K.H. Phylogenetic identification and in-situ detection of individual microbial cells without cultivation. Microbiol. Rev. 59, 143169(1995).

43. Cottrell, M.T., Moore, J.A. \& Kirchman, D.L. Chitinases from uncultured marine

44. Cowan, D.A. Microbial genomes-the untapped resource. Trends Biotechnol. 18, 14-16 (2000).

45. Henne, A., Schmitz, R.A., Bomeke, M., Gottschalk, G. \& Daniel, R. Screening of environmental DNA libraries for the presence of genes conferring lipolytic activity on Escherichia coli. Appl. Environ. Microbiol. 66, 3113-3116 (2000).

46. Rondon, M.R. et al. Cloning the soil metagenome: a strategy for accessing the genetic and functional diversity of uncultured microorganisms. Appl. Environ. Microbiol. 66, 2541-2547 (2000).

47. Petrounia, I.P. \& Arnold, F.H. Designed evolution of enzymatic properties. Curr. Opin. Biotechnol. 11, 325-330 (2000).

48. Jaenicke, R. \& Bohm, G. The stability of proteins in extreme environments. Curr. Opin. Struct. Biol. 8, 738-748 (1998).

49. Malakauskas, S.M. \& Mayo, S.L. Design, structure and stability of a hyperther-mophilic protein variant. Nat. Struct. Biol. 5, 470-475 (1998).

50. Chen K. \& Arnold, F. Tuning the activity of an enzyme for unusual environments: sequential random mutagenesis of subtilisin $\mathrm{E}$ for catalysis in dimethylformamide. Proc. Natl. Acad. Sci. USA 90, 5618-5622 (1993).

51. Wfehtje, E. \& Adlercreutz, P. Water activity and substrate concentration effects on lipase activity. Biotechnol. Bioeng. 55, 798-806 (1997).

52. Burton, S.G., Duncan, J.R., Kaye P.T. \& Rose P.D. Activity of mushroom polyphenol oxidase in organic medium. Biotechnol. Bioeng. 42, 938-946 (1994).

53. Reimann, A., Robb, D.A. \& Halling, P.J. Solvation of CBZ-amino acid nitrophenyl esters in organic media and the kinetics of their transesterification by subtilisin. Biotechnol. Bioeng. 43, 1081-1086 (1994).

54. Khemelnitsky, Y.L., Welch, S.H., Clark, D.S \& Dordick, D.S. Salts dramatically enhance activity of enzymes suspended in organic solvents. J. Am. Chem. Soc.116, 2647-2648 (1994). 
55. Ru, M.T., Dordick, J.S., Reimer, J.A. \& Clark, D.S. Optimising the salt-induced activation of enzymes in organic solvents:effects of lyophilisation time and water content. Biotechnol. Bioeng. 63, 233-241 (1999).

56. Schmid, A., Dordick, J.S., Haven, B., Wubbolts, M. \& Witholt, B. Industrial biocatal-ysis today and tomorrow. Nature 409, 258-268 (2001).

57. Liese, A., Seelbach, K. \& Wandrey, C. Industrial biotransformations. (Wiley-VCH, Weinheim, Germany; 2000).

58. Wfeng, P., Sergeeva, M.V., Lim, L. \& Dordick J.S. Biocatalyst plastics as active and stable materials for biotransformations. Nat. Biotechnol. 15, 789-793 (1997).

59. Partridge, J., Halling, P.J. \& Moore, B.D. Practical route to high activity enzyme preparations for synthesis in organic media. Chem. Commun. 7, 841-842 (1998).

60. Rich, J.O. \& Dordick, J.S. Controlling subtilisin activity and selectivity in organic media by imprinting with nucleophilic substrates. J. Am. Chem. Soc. 119, 3245-3252 (1997).

61. Slade C.J. \& Vulfson, E.N. Induction of catalytic activity in proteins by lyophilization in the presence of a transition state analogue. Biotechnol. Bioeng. 57, 211-215 (1998).

62. Reetz, M.T., Zonta, A., Schimossek, K., Liebeton, K. \& Jaeger, K.-E. Creation of enantioselective biocatalysts for organic chemistry by in vitro evolution. Angew. Chem., Int. Edn. Engl. 36, 2830-2833 (1997).

63. Bornscheuer, U.T, Altenbuchner, J. \& Meyer, H.H. Directed evolution of an esterase for the stereoselective resolution of a key intermediate in synthesis of epithilones. Biotechnol. Bioeng. 58, 554-559 (1998).

64. Sutherland, J.D. Evolutionary optimization of enzymes. Curr. Opin. Chem. Biol. 4,263269 (2000).

65. Broun, P., Shanklin, J., Whittle, E. \& Somerville, C. Catalytic plasticity of fatty acid modification enzymes underlying chemical diversity of plant lipids. Science 282, 13151317 (1998).

66. Zhang, J.H., Dawes, G., \& Stemmer, WP. Directed evolution of a fucosidase from a galactosidase by DNS shuffling and screening. Proc. Natl. Acad. Sci. US A 94, 45044509 (1997).

67. Zhao, H. \& Arnold, F Directed evolution converts subtilisin E into a functional equivalent of thermitase. Protein Eng. 12, 47-52 (1999).

68. Fernandez-Lafuente, R., Cowan, D.A. \& Wood, A.N.P. Hyperstabilisation of a thermophilic esterase by multipoint covalent attachment. En₹. Microb. Technol. 17, 366-372 (1995).

69. Kazan, D., Ertan, H. \& Eraslan, A. Stabilisation of Escherichia coli penicillin G acy-lase against thermal inactivation by cross-linking with dextran dialdehyde polymers. Appl. Microbiol. Biotechnol. 48, 191-197 (1997).

70. Haring, D. \& Schreier, P. Novel biocatalysts by chemical modification of known enzymes: cross-linked microcrystals of the semi-synthetic peroxidase seleno-subtilisin. Agnew. Chem. Int. Edn. Engl. 37, 2471-2473 (1998). 
71. Mori, T. \& Okahata, Y. A variety of lipid-coated glycoside hydrolases as effective glycosyl transfer catalysts in homogenous organic solvents. Tetrahedron Lett. 38, 1971-1974 (1997).

72. Jene, O., Pearson, J.C. \& Lowe, C.R. Surfactant modified enzymes: solubility and activity of surfactant-modified catalase in organic solvents. Enz. Microb. Technol. 20, 69-74 (2000).

73. Moore, J.C. \& Arnold, F.H. Directed evolution of a para-nitrobenzyl esterase for aqueous-organic solvents. Nat. Biotechnol. 14, 458-462 (1996).

74. Bull, A.T., Goodfellow, M. \& Slater, J.H. Biodiversity as a source of innovation in biotechnology. Ann. Rev. Microbiol. 46, 219-252 (1992)

75. Margesin, R. \& Schinner, F. Characterization of a metalloprotease from psy-chrophilic Xanthomonas maltophilia. FEMS Microbiol. Lett. 79, 257-261 (1991).

76. Gimenez, M.I., Studdert, C.A., Sanchez, J.J. \& De Castro, R.E. Extracellular protease of Natrialba magadii: purification and biochemical characterisation. Extremophiles 4, 181 188 (2000).

77. Cowan, D.A. \& Daniel, R.M. Purification and some properties of an extracellular protease (Caldolysin) from an extreme thermophile. Biochim. Biophys. Acta. 705,293-305 (1982).

78. Cowan, D.A., Smolenski, K.A., Daniel, R.M. \& Morgan, H.W. An extremely thermostable extracellular protease from a strain of the archaebacterium Desulfurococcus growing at $88^{\circ}$ C. Biochem. J. 247, 121-133 (1987). 